\title{
A reverse-transcription loop-mediated isothermal amplification (RT-LAMP) assay for detecting the pathogen of maize rough dwarf disease in China
}

\author{
Linlin $\mathrm{Du}^{1,2} \cdot$ Wenjuan $\mathrm{Shi}^{1} \cdot$ Xuejuan $\mathrm{Li}^{1} \cdot{\text { Ying } \mathrm{Lan}^{2}}^{2}$ Feng Sun ${ }^{2} \cdot$ Yongjian Fan ${ }^{2} \cdot$ Tong Zhou $^{1,2,3,4,5}$ (D) Yijun Zhou $^{1}$
}

Received: 27 March 2019 / Accepted: 3 June 2019 / Published online: 14 June 2019

(C) The Author(s) 2019

\begin{abstract}
Maize rough dwarf disease (MRDD) is one of the most serious viral diseases of maize in China. The object of this study is to develop a reverse-transcription loop-mediated isothermal amplification (RT-LAMP) assay for rapid and sensitive detection of MRDD pathogen. Four RT-LAMP primers were designed on the basis of S10. Template RNA from infected leaves were used for RT-LAMP which were carried out under isothermal conditions at $61{ }^{\circ} \mathrm{C}$ for $90 \mathrm{~min}$. RT-LAMP products were analyzed by electrophoresis in agarose gels or visual inspection of color change after staining with calcein. Sensitivity of the RT-LAMP assay was 100-fold higher than RT-PCR. This method can distinguish RBSDV from SRBSDV and the vectors carrying RBSDV from Rice stripe virus (RSV). The RT-LAMP assay shows excellent potential for application in the rapid and sensitive detection of MRDD pathogens in field samples or vector.
\end{abstract}

Keywords MRDD $\cdot$ Rapid detection $\cdot$ RT-LAMP $\cdot$ Calcein $\cdot$ Diagnosis

\section{Introduction}

Maize rough dwarf disease (MRDD) is a severe and widely spread disease caused by three closely related members of the genus Fijivirus, family Reoviridae: Rice black streaked dwarf

Linlin Du and Wenjuan Shi contributed equally to this work.

Tong Zhou

loxboy@126.com

Yijun Zhou

2690065830@qq.com

1 College of Plant Protection, Nanjing Agricultural University, Nanjing 210095, China

2 Jiangsu Key Laboratory for Food Quality and Safety-State Key Laboratory Cultivation Base, Institute of Plant Protection, Jiangsu Academy of Agricultural Sciences, Nanjing 210014, Jiangsu Province, China

3 School of the Environment and Safety Engineering, Jiangsu University, Zhenjiang 212013, Jiangsu, Province, China

4 Institute of Life Sciences, Jiangsu University, Zhenjiang 212013, Jiangsu, Province, China

5 International Rice Research Institute and Jiangsu Academy of Agricultural Sciences Joint Laboratory, Nanjing 210095, China virus (RBSDV), Mal de Rio Cuarto virus (MRCV) and Maize rough dwarf virus (MRDV) (Lenardon et al. 1998; Bai et al. 2002; Dovas et al. 2004). In China, the MRDD pathogen is RBSDV (Wang et al. 2003), which is also transmitted efficiently to rice (Wang et al. 2006a), wheat (Zhang et al. 2001), barley (Zhou et al. 2010) and other cereals (Wang et al. 2006a) by small brown planthoppers (Laodelphax striatellus Fallén, SBPH) (Ruan et al. 1984). Recently, Southern rice black-streaked dwarf virus (SRBSDV) is a new species in the genus Fijivirus Group 2 within the family Reoviridae (Zhang et al. 2008; Zhou et al. 2008), which is transmitted efficiently to rice and maize by the white backed planthopper (WBPH, Sogatella furcifera). Maize infected by SRBSDV showed the same symptoms as infected by RBSDV (Zhou et al. 2008). In China, the occurrence of MRDD showed a significant upward trend with the changes in climate, environment and adjustment of planting structures in recent years (Tao et al. 2013). The accurate and efficient detection of pathogens is essential for forecasting and controlling the spread of MRDD.

Several methods for detecting RBSDV were developed, such as biological detection (Zhang et al. 2001), electron microscopy (Zhou et al. 1998), enzyme-linked immunosorbent assay (ELISA) (Wang et al. 2006b) and RT-PCR (Wu et al. 
2000). RT-PCR is more accurate but may not be suitable for a rapid testing within a short period of time. Thus, a simple and convenient method should be developed for detecting the MRDD pathogen. The reverse-transcription loop-mediated isothermal amplification (RT-LAMP) reaction occurs under isothermal conditions (Notomi et al. 2000). The results of the reaction can be observed by adding a fluorescent indicator calcein or through the direct visualization of precipitation in the tubes (Tomita et al. 2008; Mori et al. 2001). RT-LAMP was widely applied for the detection of pathogens (Keizerweerd et al. 2015; Hu et al. 2016; Yoshikawa et al. 2014; Gao et al. 2015; Nair et al. 2016). Here, the RTLAMP assay was developed for rapid and sensitive detection of the MRDD pathogen of maize and the small brown planthopper.

\section{Materials and methods}

\section{Maize samples and vector}

Eight maize samples showing stunting and dark-green leaves symptoms were collected from the fields of Jiangsu Academy of Agricultural Sciences in the summer of 2015, and four maize samples showing stunting and dark-green leaves symptoms were collected from the fields of Hainan province of China in 2014.

SBPH with RSV were preserved previously. SBPH without RSV were fed on rice seedlings (Wuyujing 3) (Zhou et al. 2012a). When SBPH grew to 3rd instar, they were placed on fresh rice seedlings infected with RBSDV for 3 days to achieve viral infection. The surviving SBPH were fed on rice seedlings (Wuyujing 3) for 12-15d to cycle through the circulative period (Zhou et al. 2011).

All samples were tested by RT-PCR (Ji et al. 2011), and positive samples were stored at $-80^{\circ} \mathrm{C}$.

\section{Primer design}

Based on the sequences of the highly conserved regions of the coat protein gene sequences of RBSDV, four oligonucleotide primers were designed using PrimerExplorer V4 software (http://primerexplorer.jp/elamp4.0.0/index.html) using the default settings. The primers were derived from the S10 region of the viral genome, and details are listed in Table 1.

\section{Total RNA}

Total RNA was extracted from the maize leaves or SBPH using TRIzol $®$ Reagent (Invitrogen, CA, USA) according to the manufacturer's protocol with modifications for the volume of the reagents added. Briefly, approximately $100 \mathrm{mg}$ of leaf tissue or a single SBPH that had cycled through the circulative period were mixed with $1.0 \mathrm{~mL}$ or $350 \mu \mathrm{L}$ TRIzol reagent, respectively, for $5 \mathrm{~min}$. At the final step, the RNA was resuspended in $35 \mu \mathrm{L}$ or $20 \mu \mathrm{L}$ DEPC-treated water, respectively. The RNA concentration was determined by spectrophotometric analysis (Thermo NanoDrop 2000C).

\section{RT-lamp}

RT-LAMP was carried out using maize total RNA. In a total volume of $25 \mu \mathrm{L}$, the reaction contained $1 \mu \mathrm{L}$ of maize RNA or $2 \mu \mathrm{L}$ of SBPH RNA, $0.2 \mu \mathrm{M}$ of $\mathrm{F}_{3}$ and $\mathrm{B}_{3}, 1.6 \mu \mathrm{M}$ of FIP and BIP, $8 \mathrm{mM}$ of $\mathrm{MgSO}_{4}, 0.8 \mathrm{M}$ of betaine (Sigma), $1.4 \mathrm{mM}$ of dNTPs, $0.5 \mathrm{mM}$ of $\mathrm{MnCl}_{2}, 50 \mu \mathrm{M}$ of calcein (Sangon Biotech), $1 \mu \mathrm{L}$ of $B s t$ DNA polymerase $(8 \mathrm{U} / \mu \mathrm{L}$, NEB, USA), $0.5 \mu \mathrm{L}$ of M-MuLV reverse transcriptase $(200 \mathrm{U} / \mu \mathrm{L}$, Fermentas), $0.5 \mu \mathrm{L}$ of RNase Inhibitor $(40 \mathrm{U} / \mu \mathrm{L}$, Fermentas), $20 \mathrm{mM}$ of Tris- $\mathrm{HCl}\left(\mathrm{pH} 8.8,25^{\circ} \mathrm{C}\right), 10 \mathrm{mM}$ of KCl, $10 \mathrm{mM}$ of $\left(\mathrm{NH}_{4}\right)_{2} \mathrm{SO}_{4}, 0.1 \%$ TritonX-100, and supplemental DEPCtreated water. The mixture was incubated at $61^{\circ} \mathrm{C}$ for $90 \mathrm{~min}$, followed by $5 \mathrm{~min}$ at $80^{\circ} \mathrm{C}$.

The RT-LAMP products were evaluated by direct visual inspection of color change in the reaction tube as well as by examining the presence or absence of the characteristic white pyrophosphate precipitate in each reaction tube following centrifugation. In addition, $2 \mu \mathrm{L}$ of products were checked for purity and size by ethidium bromide staining after agarose gel electrophoresis (1\% agarose, TAE).

\section{Sensitivity and specificity of RT-LAMP}

To determine the specificity of the RT-LAMP, total RNA from maize leaf infected with SRBSDV or RBSDV was applied independently to the reaction mix. The optimized reaction system was used under the appropriate conditions for carrying out the RT-LAMP assay. Water served as the blank controls. An observation was made for whether the color changed and whether the precipitate emerged after the reaction finished.

\section{Results \\ RT-lamp}

The maize samples exhibited ladder-like DNA fragments after agarose gel electrophoresis (Fig. 1a and c). No visible DNA amplification was observed in the template-less water control, indicating that the primer design and reaction conditions were suitable for virus detection. The optimal conditions for RTLAMP was $61{ }^{\circ} \mathrm{C}$ (Fig. 1a), minimum 90 min reaction time (Fig. 1c), $8 \mathrm{mM} \mathrm{Mg}^{2+}, 0.5 \mathrm{mM} \mathrm{Mn}^{2+}, 50 \mu \mathrm{M}$ calcein, $0.2 \mu \mathrm{M}$ internal primer and $1.6 \mu \mathrm{M}$ external primer. 
Table 1 The four oligonucleotide primers used in the RT-LAMP assay for the detection of MRDD

\begin{tabular}{lllll}
\hline Primer name & Type & Length & Genome position & Sequences $\left(5^{\prime}-3^{\prime}\right)$ \\
\hline F3 & Forward outer & $19-\mathrm{mer}$ & $803-821$ & TTTCGGCTTTGAAAACAGT \\
B3 & Backward outer & $19-\mathrm{mer}$ & $1000-982$ & TGCCATCGTAATTAGTGCG \\
FIP $\left(\mathrm{F} 1 \mathrm{c}+\mathrm{F}_{2}\right)$ & Forward inner & $43-\mathrm{mer}$ & $891-872,831-853$ & TGCGCTCCAAGTTTGTTCGATGAAAAAGAACTAAGTGTTTTGG \\
BIP $\left(\mathrm{B} 1 \mathrm{c}+\mathrm{B}_{2}\right)$ & Backward inner & $43-\mathrm{mer}$ & $900-924,978-960$ & ATTTGTTGAAACATGGCAGGTTAAACGTGGACAAACTG \\
& & & & GTCAAT \\
\hline
\end{tabular}

Genome position according to the reference nucleotide sequence of RBSDV, accession no. AJ297433.1

\section{Sensitivity of the RT-LAMP amplification compared with RT-PCR}

To evaluate the relative sensitivity of the assays, RT-LAMP and RT-PCR were carried out using a series of tenfold dilutions of total RNA extracted from RBSDV infected maize, ranging from 1.1 to $1.1 \times 10^{-8} \mu \mathrm{g}$ per reaction. Positive RTLAMP amplifications were observed up to dilutions of $1.1 \times$ $10^{-6} \mu \mathrm{g}$ (Fig. 2a, c), while the RT-PCR gave positive results up to dilutions of $1.1 \times 10^{-4} \mu \mathrm{g}$ (Fig. 2b). The assays performed with total RNA at $1.1 \times 10^{-7} \mu \mathrm{g}$ or lower did not show consistent or detectable product yields in either assay. Thus, the RT-LAMP assay was one hundred times more sensitive than the RT-PCR for MRDD pathogen detection.

\section{Specificity of RT-LAMP}

The specificity of the RT-LAMP assay for the detection of the MRDD pathogen was determined by determining its cross-

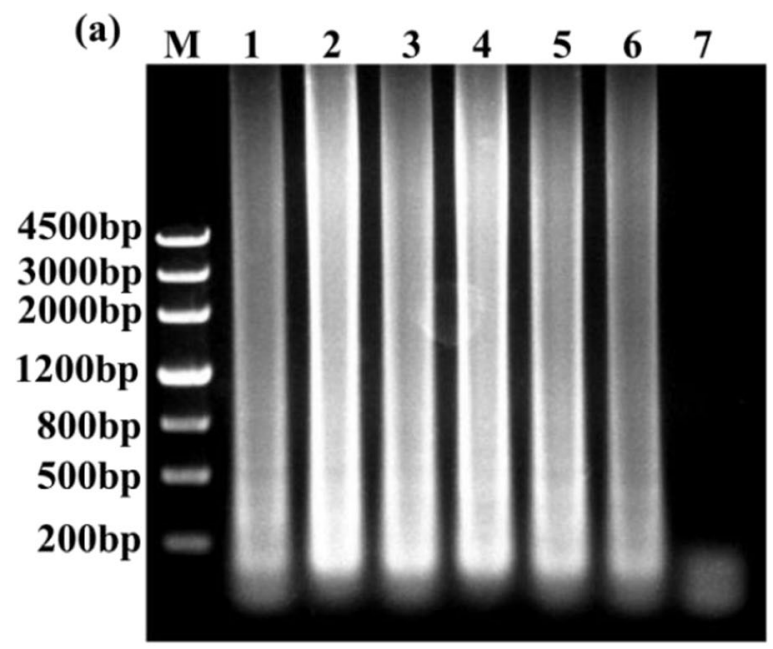

(b)

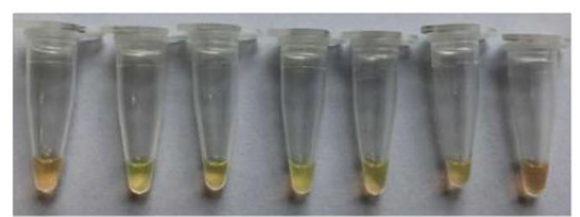

Fig. 1 RT-LAMP for the detection of MRDD showing the optimum reaction temperature and time. M, DNA marker III;(a, b) Different temperature (lanes $1-6,60-65{ }^{\circ} \mathrm{C}$ respectively; lane 7 , negative reactivity with the closely related SRBSDV and RSV. Total RNA from maize leaf infected with either RBSDV or SRBSDV (Fig. 3a) or from vector carrying RBSDV or RSV (Fig. 3b) was independently amplified. In both types of samples (host and vector) carrying RBSDV, the RT-LAMP product could be easily visualized by observing the color change. In contrast, in both types of samples carrying SRBSDV or RSV, there were no observable changes. Thus, the RTLAMP primer set demonstrated a high degree of specificity for RBSDV.

\section{Discussion}

The disease caused by RBSDV has recently became one of the most damaging maize crop disease in China and led to significant economic loss (Zhang et al. 2008; Zhou et al. 2008, 2012a, b). MRDD need to be monitored and diagnosed at the early stages for forecasting and controlling the spread of

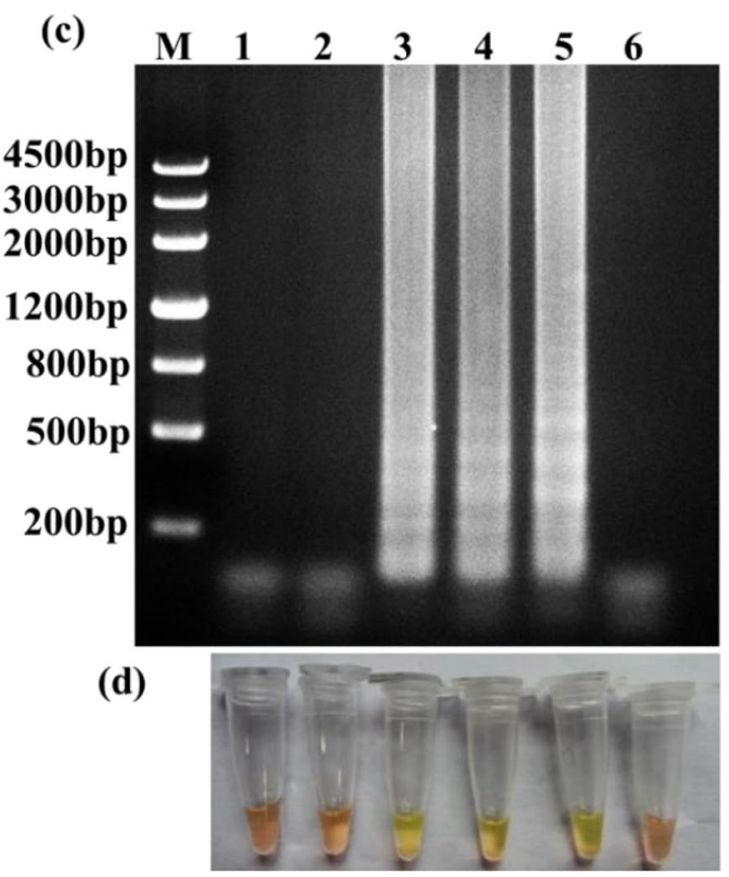

control). (c, d) Different time (lane 1, $30 \mathrm{~min}$; lane 2, $60 \mathrm{~min}$; lane 3,90 min; lane 4, $120 \mathrm{~min}$; lane 5, $150 \mathrm{~min}$; lane 6, negative control) 
(a)

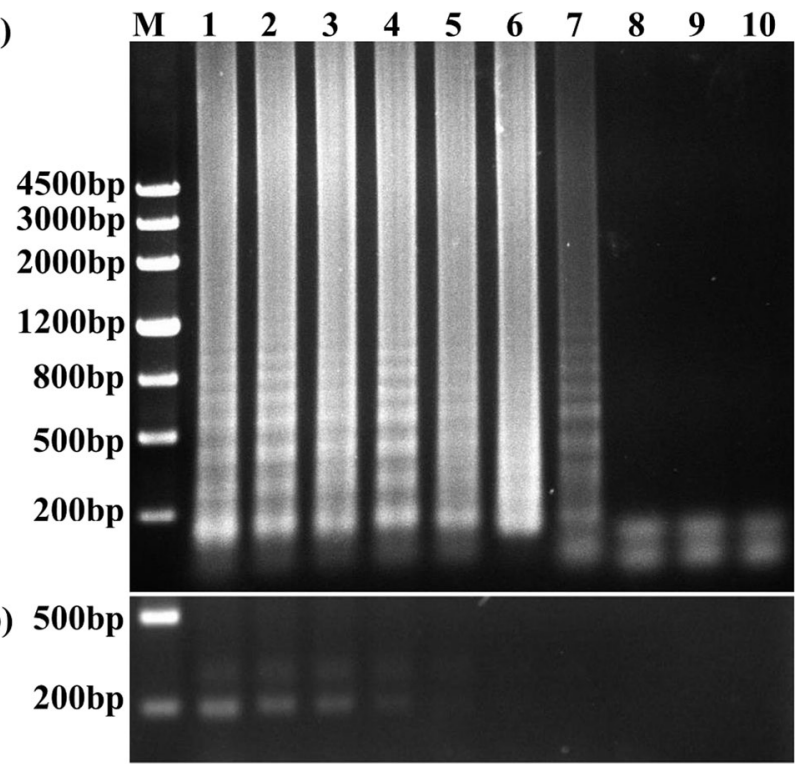

(c)

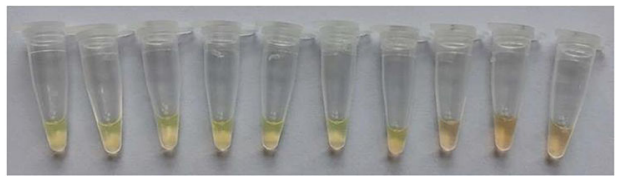

Fig. 2 The sensitivity of the RT-LAMP (a, c) compared with RT-PCR assay (b). M, DNA marker III; lanes $1-9,1.1$ to $1.1 \times 10^{-8} \mu \mathrm{g}$ per reaction; lanes 10 , negative control

virus diseases. RT-LAMP is a sensitive diagnostic technique based on amplification of reverse transcribed cDNA in a relatively short time and at a single reaction temperature, and there is no time loss for temperature change as in PCR or real-time PCR (Notomi et al. 2000). Electrophoresis
1

(a)

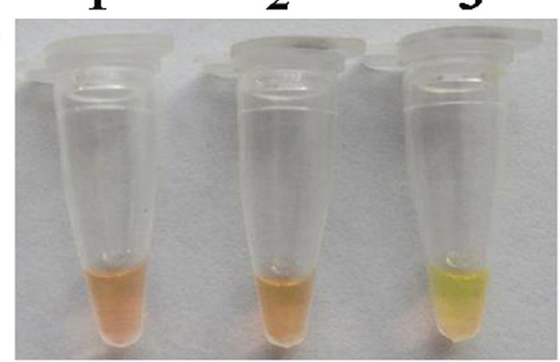

(b)

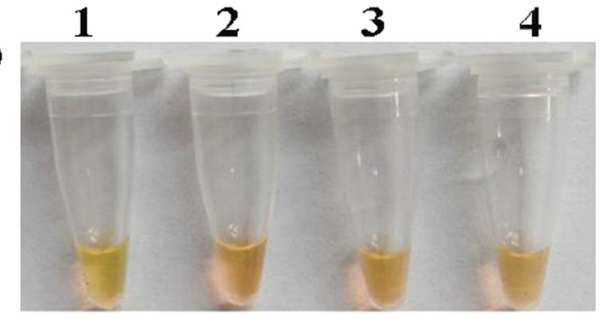

Fig. 3 The specificity of the RT-LAMP assay for detection of RBSDV (a) Maize leaf tissue infected with either RBSDV or SRBSDV (lane 1, Negative control; lane 2, SRBSDV; lane 3, RBSDV). (b) Vector carrying RBSDV or RSV (lane 1, vector with RBSDV; lane 2, vector without RBSDV; lane 3, vector with RSV; lane 4, Negative control) equipment and gel imaging systems were also not necessary for the RT-LAMP. This method has been widely used in detection of various pathogens, especially for detection of viruses which cause similar symptoms in a host and show a high nucleotide homology (Zhao et al. 2010). In this study, four RTLAMP primers were designed on the basis of S10, and the concentrations of the primers, the best reaction temperature and time for detecting the virus were observed, respectively. The specificity and sensitivity of RT-LAMP were tested. MRDD pathogeny could be detected in total RNA extracts diluted up to $1.1 \times 10^{-6} \mu \mathrm{g}$, which is one hundred times more sensitive than the RT-PCR method.

In this study, calcein was used as the fluorescence indicator, the detection results could be directly judged by observing the color changes. Calcein was added into the reaction system before the reaction began (Dong et al. 2015; Luo et al. 2016; Jiang et al. 2017), which avoided the false positives resulted from the reaction product contamination easily occurred from opening the lids. In the RT-LAMP assay for detection of SRBSDV (Zhou et al. 2012a) and RBSDV (Zhou et al. 2012b), SYBR Green I as the fluorescence indicator was added after the reaction was finished by opening the lids, that increased the rate of false positives. A rapid and specific RT-LAMP method was established for detection of MRDD pathogen in maize and a single small brown planthopper. The RT-LAMP may be useful for preventing MRDD occurrence and spread.

Acknowledgments This work was supported by National Natural Science Foundation of China (NSFC)-International Rice Research Institute (IRRI) project (31761143012); The National Key R\&D Program of China (2017YFD0100400); Six talent peaks project of Jiangsu Province (NY-056); 333 high level talent training project of Jiangsu Province (BRA2018081).

Open Access This article is distributed under the terms of the Creative Commons Attribution 4.0 International License (http:// creativecommons.org/licenses/by/4.0/), which permits unrestricted use, distribution, and reproduction in any medium, provided you give appropriate credit to the original author(s) and the source, provide a link to the Creative Commons license, and indicate if changes were made.

\section{References}

Bai FW, Yan J, Qu ZC, Zhang HW, Xu J, Ye MM, Shen DL (2002) Phylogenetic analysis reveals that a dwarfing disease on different cereal crops in China is due to rice black streaked dwarf virus (RBSDV). Virus Genes 25:201-206

Dong ZM, Liu PQ, Li BJ, Chen GL, Weng QY, Chen QH (2015) Loopmediated isothermal amplification assay for sensitive and rapid detection of Phytophthora capsici. Can J Plant Pathol 37:485-494

Dovas CI, Eythymiou K, Kats NI (2004) First report of maize rough dwarf virus (MRDV) on maize crops in Greece. Plant Pathol 53:238

Gao S, Li D, Liu Y, Zha E, Wang S, Li Y, Zhou T, Yue X (2015) Development and evaluation of a RT-LAMP assay for rapid detection of hepatitis E virus from shellfish. Int J Food Microbiol 220:1-5 
Hu SK, Niu LN, Luo LJ, Song XP, Liu QY (2016) Rapid, sensitive detection of Bartonella quintana by loop-mediated isothermal amplification of the groEL Gene. Int J Mol Sci 17:1902

Ji YH, Gao RZ, Zhang Y, Cheng ZB, Zhou T, Fan YJ, Zhou YJ (2011) A simplified method for quickly detection of rice black-streaked dwarf virus and southern rice black-streaked dwarf virus. Chin J Rice Sci 25:91-94

Jiang MT, Luo XW, Zhang DY, Zhou XG, Ouyang X, Zhang ZH, Li F, Zhang SB, Liu Y (2017) A single-step reverse transcription loopmediated isothermal amplification assay for rapid and accurate detection of pepper vein yellows virus. Can J Plant Pathol 39:212-217

Keizerweerd AT, Chandra A, Grisham MP (2015) Development of a reverse transcription loop-mediated isothermal amplification (RTLAMP) assay for the detection of sugarcane mosaic virus, and Sorghum mosaic virus in sugarcane. J Virol Methods 212:23-29

Lenardon SL, March GJ, Nome SF, Ornaghi JA (1998) Recent outbreak of "Mal de Rio Cuarto" virus on corn in Argentina. Plant Dis 82:448

Luo XW, Zhang DY, Zheng LM, Peng J, Li F, Zhang SB, Liu Y (2016) Development of a reverse transcription loop-mediated isothermal amplification assay for the rapid detection of pepper mottle virus. Can J Plant Pathol 38:506-510

Mori Y, Nagamine K, Tomita N, Notomi T (2001) Detection of loopmediated isothermal amplification reaction by turbidity derived from magnesium pyrophosphate formation. Biochem Biophys Res Commun 289:150-154

Nair S, Manimekalai R, Ganga RP, Hegde V (2016) Loop mediated isothermal amplification (LAMP) assay for detection of coconut root wilt disease and arecanut yellow leaf disease phytoplasma. World J Microbiol Biotechnol 32:1-7

Notomi T, Okayama H, Masubuchi H, Yonekawa T, Watanabe K, Amino N, Hase T (2000) Loop-mediated isothermal amplification of DNA. Nucleic Acids Res 28:e63-e663

Ruan YL, Jing DH, Xu RF, Jiang WL, Jin DD (1984) Research on rice black-streaked dwarf disease. Journal of Zhejiang Agricultural Sciences 4:185-187

Tao YF, Liu QC, Xu ML (2013) Research progress on maize rough dwarf disease. Journal of Maize Sciences 21:149-152

Tomita N, Mori Y, Kanda H, Notomi T (2008) Loop-mediated isothermal amplification (LAMP) of gene sequences and simple visual detection of products. Nat Protoc 3(5):877-882

Wang ZH, Fang SG, Xu JL, Sun LY, Li DW, Yu JL (2003) Sequence analysis of the complete genome of rice black-streaked dwarf virus isolated from maize with rough dwarf disease. Virus Genes 27:163168
Wang F, Qin GZ, Sui ZH, Wang ZH, Wang ZY, Yu JL, Zhang JR (2006a) Improved method for assaying maize plant resistance to maize rough dwarf disease by artificial inoculation and real-time RT-PCR. Eur J Plant Pathol 116:289-300

Wang ZH, Fang SG, Zhang ZY, Han CG, Li DW, Yu JL (2006b) Development of an ID-ELISA for the detection of rice blackstreaked dwarf virus in plants. J Virol Methods 134:61-65

Wu SH, Wang ZH, Fan YJ, Zhou YJ, Cheng ZB, Zhang WH (2000) Detection of pathogen of maize rough dwarf disease (MRDD) in Jiangsu province with RT-PCR. Journal of Agricultural Biotechnology 8:369-372

Yoshikawa T, Matsuo T, Kawamura Y, Ohashi M, Yonekawa T, Kanda H, Notomi T, Ihira M (2014) Direct detection of human herpesvirus 6B by the LAMP method using newly developed dry-reagents. J Virol Methods 201:65-67

Zhang HM, Lei JL, Chen JP, Lu YP, Chen SX, Xue QZ, Adams MJ (2001) A dwarf disease on rice, wheat and maize from Zhejiang and Hebei is caused by rice black-streaked dwarf virus. Virol Sin 16:246-251

Zhang HM, Yang J, Chen JP, Adams MJ (2008) A black-streaked dwarf disease on rice in China is caused by a novel Fijivirus. Arch Virol 153:1893-1898

Zhao K, Liu Y, Wang XF (2010) Reverse transcription loop-mediated isothermal amplification of DNA for detection of barley yellow dwarf viruses in China. J Virol Methods 169:211-214

Zhou YJ, Fan YJ, Cheng ZB, Wu SH, Hou QS, Wang SB (1998) Studies on virus disease of maize in Jiangsu Provincel. Preliminary identification of pathogen and Occurence of maize rough dwarf disease. Jiangsu Journal of Agricultural Sciences 14:246-248

Zhou GH, Wen JJ, Cai DJ, Li P, Xu DL, Zhang SG (2008) Southern rice black-streaked dwarf virus: a new proposed Fijivirus species in the family Reoviridae. Chin Sci Bull 53:3677-3685

Zhou T, Wang Y, Fan YJ, Cheng ZB, Zhou YJ (2010) First report of rice black-streaked dwarf virus infecting barley in Jiangsu. China J Plant Pathol 92:118

Zhou T, Wang Y, Wu LJ, Fan YJ, Zhou YJ (2011) Method of artificial inoculation identification of rice cultivar resistance to rice blackstreaked dwarf. Acta Phytophylacica Sinica 38:301-305

Zhou T, Du LL, Fan YJ, Zhou YJ (2012a) Reverse transcription loopmediated isothermal amplification of RNA for sensitive and rapid detection of southern rice black-streaked dwarf virus. J Virol Methods 180:91-95

Zhou T, Du LL, Fan YJ, Zhou YJ (2012b) Development of a RT-LAMP assay for rapid detection of Rice black-streaked dwarf virus. Sci Agric Sin 45:1285-1292 